\title{
Case reports and research productivity among Syrian medical students: Review, reality, and suggested solutions
}

\author{
Naji Alhamid, Nawar Almounayer ${ }^{1}$, Bana Alsabbagh, Baseel Atassi²
}

Nephrology resident, Damascus Department of Health, Damascus, Syria, ${ }^{1}$ Medical student, Damascus University, College of Medicine, ${ }^{2}$ Department of Internal Medicine, Hematology and Oncology, Chicago, Illinois, USA

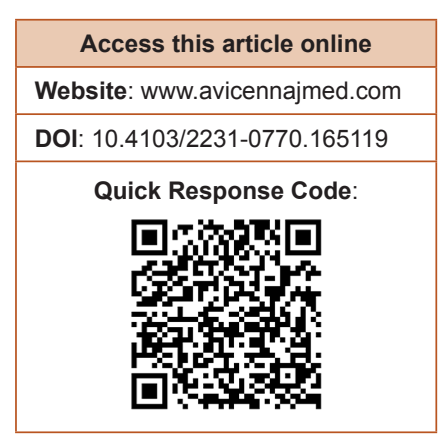

\section{ABSTRACT}

Medical students are precious seeds for better future medical research. Case reports writing may represent a relatively simple first step for beginners. Only 47 case reports are published in the literature by Syrian Medical Institutions compared to more than 500 case reports in a comparable country in the last 5 years. Many obstacles stand against developing fruitful research environment in Syria. Increasing awareness to research productivity in Syria along with comparative analysis is discussed in this article.

Key words: Research productivity, medical students, case reports

\section{INTRODUCTION}

Case report is a type of medical literature that represents unique presentation, describes unusual findings or documents a rare disease. Case reports are valuable not only due to the fact that they describe unusual cases, but also they provide an important base for further and more reliable research studies. Usually, limited usefulness in evidence-based practice and bedside clinical decision are expected from such reports. Participation of medical students in research has made important changes in the history of medicine. For instance, in 1921 insulin discovery and purification was made by the researcher Frederick Banting and his $2^{\text {nd }}$ year medical student assistant Charles Best. ${ }^{[1]}$ Multiple reports described the basic principles of writing case reports. ${ }^{[2]}$ This is the first review that focuses on Syrian research productivity in case reports and highlights the medical student's activity in this field of medicine.

\section{WHY SHOULD MEDICAL STUDENTS START WITH CASE REPORTS?}

Case report is a simple research writing experience. It is a primitive step for medical students in practicing manuscripts

Address for correspondence: Dr. Naji Alhamid, Damascus

University, College of Medicine, Damascus, Syria.

E-mail: Dr.najihamid@gmail.com writing and a valuable publication exercise for beginners. Its methodological simplicity may promote the students' abilities in searching the literature, discuss and report their rare clinical findings, enhance their readings, and improve their writing skills. In addition, it could enrich the curriculum vita that distinguishes the authors among their peers and help in pursuing better future academic careers.

\section{METHODS}

We explored all common literature search engines (PubMed, Medline, Google Scholar) for all published case reports with the following keywords: (Syria, Syrian Medicine, Damascus University, Aleppo University, Tishreen University, Albaath University, Alforat University, Alkalamoon University, Damascus, Aleppo, Latakia). In the search options, we included articles that the first or last authors are from a Syrian Medical Institution. By comparative analysis, we chose another Arab country that contains the same number

This is an open access article distributed under the terms of the Creative Commons Attribution-NonCommercial-ShareAlike 3.0 License, which allows others to remix, tweak, and build upon the work non-commercially, as long as the author is credited and the new creations are licensed under the identical terms.

For reprints contact: reprints@medknow.com

Cite this article as: Alhamid N, Almounayer N, Alsabbagh B, Atassi B. Case reports and research productivity among Syrian medical students: Review, reality, and suggested solutions. Avicenna J Med 2015;5:101-5. 
of medical schools and similar populations' background which is Tunisia. We compared publications achievements and the number of published case reports.

\section{RESULTS}

Only 47 case reports from Syrian medical institutes are available in the online published medical literature [Figure 1], 38\% of them were published in the period of 2010-2014, 54\% from Damascus University, 82\% were indexed in PubMed. Eighteen percent of the published case reports are in the field of cardiology, and the majority of cardiology cases are published by the Cardiovascular Surgical Center at Damascus University. Thirteen percent of the cases were in dentistry, $11 \%$ in nephrology and oncology [Table 1]. We were not able to determine if any medical students were involved as authors. Comparing these results to case reports published from Tunisia, we found more than 500 published case reports indexed by PubMed in the last 5 years.

\section{DISCUSSION}

This article aims to highlight Syrian medical student's activity in the medical research field, focusing on case reports. Here, we try to explore the main reasons for poor research productivity and possible solutions.

Medical students understanding of being a physician-scientist is crucial. Although they believe in the importance of research, actions toward obtaining opportunities are lacking. Burgoyne et al. ${ }^{[3]}$ stated that medical students have a narrow definition of research and what it entails, according to his study; the majority of medical students who are not interested in a career incorporating research, answered that they will avoid it



Figure 1: Published case reports since 1980 because of the isolation from patients and clinical practice. In Syria, the only research experience medical students get exposed to during their 6-years medical school is the practical part of preventive medicine during their fifth year, which represents a small cross-sectional study, as part of the curriculum and a mandatory requirement to pass to the sixth year, which lacks any planned intentions to allow student to apply creative ideas or open doors for more discoveries, adding to the fact that schools do not have supportive systems for writing skills or experience in publications.

Diab et al. ${ }^{[4]}$ showed a major deficiency in research productivity in the Syrian medical community. The published medical papers from Syria are in the second level behind agriculture publications, and count only 593 papers which represents the total number of publications from Syrian Medical Institutions. ${ }^{[4]}$ This gap has many reasons; primarily is the lack of research educative materials and support system at the medical schools levels.

The importance of focusing on medical students comes from what Diez et al. ${ }^{[5]}$ demonstrated; medical students who were involved in research projects while they were at the medical school had superior research productivity after graduation. In addition, National Institute of Health (NIH) presented an excellent mode ${ }^{[6]}$ when they responded to the alarm they identified with the decreased number of physician-scientists in the United States. Many attempts focusing on $\mathrm{MD} / \mathrm{PhD}$ programs tried to reverse this trend, but NIH focused on medical students. They reported their experience and success when they sponsored Medical Student Research Fellowship Programs for 25 years at the University of Tennessee Health Science Center and Vanderbilt University, NIH program enrolled medical students in summer research projects with a specific program and scientists mentorship. After follow-up, the vast majority of students conducted additional research after their medical student research experience, and a large number of students were doing research or had published or presented their work at scientific meetings. Many obstacles prevent medical students from conducting research were discussed in the medical literature, but in the Middle East World, a cross-sectional study conducted at the King Saud University in Saudi Arabia ${ }^{[7]}$ showed that lack of professional supervisor, training courses, along with time and funding were the most important causes observed. In Syria, one study evaluated medical students' educational background in evidence-based medicine (EBM), the authors found a significant positive attitude toward improving EBM knowledge and students requested adding EBM to their medical school curriculum. ${ }^{[8]}$ 


\begin{tabular}{|c|c|c|c|}
\hline Journal name & Institution & Year of publication & Title \\
\hline $\begin{array}{l}\text { The Saudi Journal for Dental } \\
\text { Research }\end{array}$ & Tishreen & 2013 & $\begin{array}{l}\text { Retraction of the upper maxillary incisors } \\
\text { with corticotomy-facilitated orthodontics } \\
\text { and mini-implants }\end{array}$ \\
\hline $\begin{array}{l}\text { Tishreen University Journal for } \\
\text { Research and Scientific Studies }\end{array}$ & Tishreen & 2011 & $\begin{array}{l}\text { Hard- and soft-tissue augmentation after } \\
\text { immediate implantation in anterior maxilla } \\
\text { with multi-disciplinary approaches; a clinical } \\
\text { report }\end{array}$ \\
\hline Journal of Digestive Diseases & Tishreen & 2014 & $\begin{array}{l}\text { Pseudoephedrine-induced ischemic colitis: } \\
\text { Case report and literature review }\end{array}$ \\
\hline $\begin{array}{l}\text { The Internet Journal of Dental } \\
\text { Science }\end{array}$ & Tishreen & 2009 & $\begin{array}{l}\text { Oral implant application following } \\
\text { free gingival graft and horizontal ridge } \\
\text { augmentation: A case report }\end{array}$ \\
\hline Pediatric Pulmonology & Tishreen & 2002 & $\begin{array}{l}\text { Laryngeal hirudiniasis: An unusual cause of } \\
\text { airway obstruction and hemoptysis }\end{array}$ \\
\hline Journal of Cardiac Surgery & Damascus University & 2011 & $\begin{array}{l}\text { Pelvic intravenous leiomyomatosis with } \\
\text { transcaval extension to the heart and } \\
\text { pulmonary arteries }\end{array}$ \\
\hline Pediatric Radiology & Damascus University & 2009 & Splenorenal fusion in a 26 -month-old girl \\
\hline Pediatric Neurosurgery & $\begin{array}{l}\text { Moassat University Hospital } \\
\text { Division of Pediatric Neurosurgery, } \\
\text { Department of Neurosurgery }\end{array}$ & 2007 & $\begin{array}{l}\text { Unclassified scaphocephaly with a large } \\
\text { posterior parietooccipital bony abnormality }\end{array}$ \\
\hline Child's Nervous System & $\begin{array}{l}\text { Moassat University Hospital } \\
\text { Division of Pediatric Neurosurgery, } \\
\text { Department of Neurosurgery }\end{array}$ & 2004 & $\begin{array}{l}\text { Late appearance of hydrocephalus } \\
\text { associated with posttraumatic intradiploic } \\
\text { arachnoid cyst }\end{array}$ \\
\hline $\begin{array}{l}\text { Asian Cardiovascular and Thoracic } \\
\text { Annals }\end{array}$ & Damascus University & 2003 & Giant substernal goiter with chylothorax \\
\hline The Journal of Heart Valve Disease & $\begin{array}{l}\text { Damascus University (cardiovascular } \\
\text { surgical center) }\end{array}$ & 2000 & $\begin{array}{l}\text { The mitral pulmonary autograft: } A \text { follow-up } \\
\text { cautionary report }\end{array}$ \\
\hline Gastrointestinal Endoscopy & $\begin{array}{l}\text { AL-Assad University Hospital } \\
\text { Gastroenterology Center }\end{array}$ & 1997 & $\begin{array}{l}\text { The whirlpool jet technique for removal of } \\
\text { pancreatic duct ascaris }\end{array}$ \\
\hline British Journal of Urology & Moassat University hospital (urology) & 1994 & $\begin{array}{l}\text { The use of a buccal mucosa patch } \\
\text { graft in the management of a large } \\
\text { urethrocutaneous fistula }\end{array}$ \\
\hline $\begin{array}{l}\text { The Journal of Cardiovascular } \\
\text { Surgery }\end{array}$ & Damascus University (cardiology) & 1992 & $\begin{array}{l}\text { Surgical management of cardiac } \\
\text { echinococcosis }\end{array}$ \\
\hline Arab Journal of Gastroenterology & $\begin{array}{l}\text { Division of Gastroenterology, } \\
\text { Department of Internal Medicine, School } \\
\text { of Medicine, Aleppo University }\end{array}$ & 2012 & $\begin{array}{l}\text { Sclerosing mesenteritis: A rare case of large } \\
\text { bowel and rectum involvement }\end{array}$ \\
\hline $\begin{array}{l}\text { Current Opinion in Endocrinology, } \\
\text { Diabetes and Obesety }\end{array}$ & Aleppo & 2001 & $\begin{array}{l}\text { Hypokalemia in pregnancy: Clue to } \\
\text { Gitelman syndrome }\end{array}$ \\
\hline Angiology, The Journal of Vascular & & 1983 & Persistent eustachian valve causing severe \\
\hline Disease & & & $\begin{array}{l}\text { cyanosis in atrial septal defect with normal } \\
\text { right heart pressures }\end{array}$ \\
\hline Chest & $\begin{array}{l}\text { From the Divison of Cardiology, } \\
\text { Department of Medicine, Damascus } \\
\text { University School of Medicine }\end{array}$ & 1980 & Hypocalcemic cardiomyopathy \\
\hline $\begin{array}{l}\text { International Journal of Pediatric } \\
\text { Dentistry }\end{array}$ & $\begin{array}{l}\text { Department of pediatric dentistry } \\
\text { Damascus University School of Dentistry }\end{array}$ & 2002 & $\begin{array}{l}\text { Riga-Fede disease:Association with } \\
\text { microcephaly }\end{array}$ \\
\hline Angiology & $\begin{array}{l}\text { Damascus University School of Medicine } \\
\text { and Mouassat University Hospital }\end{array}$ & 1982 & $\begin{array}{l}\text { Hypoplasia of descending aorta as a rare } \\
\text { cause of hypertension report of } 5 \text { cases }\end{array}$ \\
\hline The Annals of Thoracic Surgery & $\begin{array}{l}\text { Damascus University Cardiovascular } \\
\text { Surgical Center, Damascus, Syria }\end{array}$ & 1993 & $\begin{array}{l}\text { Atrial myxoma: Report of } 24 \text { operations } \\
\text { using the biatrial approach }\end{array}$ \\
\hline $\begin{array}{l}\text { Asian Cardiovascular and Thoracic } \\
\text { Annals }\end{array}$ & $\begin{array}{l}\text { Damascus University Cardiovascular } \\
\text { Surgical Center }\end{array}$ & 2007 & $\begin{array}{l}\text { Surgical experience with cardiac } \\
\text { echinococcosis }\end{array}$ \\
\hline $\begin{array}{l}\text { Bulletin de la Société de } \\
\text { pathologie exotique }\end{array}$ & $\begin{array}{l}\text { Hôpital Mouassat, Laboratoire Central, } \\
\text { Université de Damas, Syrie }\end{array}$ & |99| & $\begin{array}{l}\text { Human cutaneous leishmaniasis caused by } \\
\text { Leishmania major MON-26 in the region of } \\
\text { Damascus (Syria) }\end{array}$ \\
\hline $\begin{array}{l}\text { Journal of Pakistan Association of } \\
\text { Dermatologists }\end{array}$ & $\begin{array}{l}\text { Department of Dermatology and } \\
\text { Venereology,Aleppo University Hospital, } \\
\text { Syria }\end{array}$ & 2014 & $\begin{array}{l}\text { Bullous ichthyosiform erythroderma: Case } \\
\text { presentation }\end{array}$ \\
\hline The Journal of Pediatric Dentistry & $\begin{array}{l}\text { Department of Pediatric Dentistry, } \\
\text { Damascus University School of } \\
\text { Dentistry, Syria }\end{array}$ & 2001 & $\begin{array}{l}\text { Riga-Fede disease: Report of a case and } \\
\text { review }\end{array}$ \\
\hline
\end{tabular}




\begin{tabular}{|c|c|c|c|}
\hline Journal name & Institution & Year of publication & Title \\
\hline Saudi Medical Journal & $\begin{array}{l}\text { From the Department of } \\
\text { Surgery (Fakhouri), Neurosurgery } \\
\text { Division, and the Department of } \\
\text { Pathology (Frasheh), Aleppo University } \\
\text { Hospital,Aleppo, Syria }\end{array}$ & 2014 & $\begin{array}{l}\text { Primary Ewing's sarcoma of the anterior } \\
\text { fontanelle in a neonate }\end{array}$ \\
\hline $\begin{array}{l}\text { Egyptian Dermatology Online } \\
\text { Journal }\end{array}$ & $\begin{array}{l}\text { Dermatology and Venereology } \\
\text { Department, Aleppo University Hospital, } \\
\text { Aleppo, Syria }\end{array}$ & 2014 & $\begin{array}{l}\text { Autosomal recessive plasma cell panniculitis } \\
\text { with morphea-like clinical manifestation }\end{array}$ \\
\hline Clinical Nephrology & $\begin{array}{l}\text { Department of Medicine, University of } \\
\text { Aleppo,Aleppo, Syria }\end{array}$ & 2013 & $\begin{array}{l}\text { Renal cortical necrosis following a } \\
\text { colonoscopy }\end{array}$ \\
\hline Balkan Journal of Medical Genetics & $\begin{array}{l}\text { Atomic Energy Commission of Syria, } \\
\text { Damascus, Syria }\end{array}$ & 2013 & $\begin{array}{l}\text { Molecular cytogenetic characterization } \\
\text { of an inv (Y) (pII.2qII.22I q I I.222) in a } \\
\text { Syrian family }\end{array}$ \\
\hline $\begin{array}{l}\text { Clinics and Research in } \\
\text { Hepatology and Gastroenterology }\end{array}$ & $\begin{array}{l}\text { Department of Gastroenterology, } \\
\text { Saint-Louis Hospital }\end{array}$ & 2013 & $\begin{array}{l}\text { Acute recurrent pancreatitis secondary } \\
\text { to the rare association of a duodenal } \\
\text { duplication cyst and a pancreas divisum }\end{array}$ \\
\hline Molecular Cytogenetics & $\begin{array}{l}\text { Atomic Energy Commission, Damascus, } \\
\text { Syria }\end{array}$ & 2010 & $\begin{array}{l}\text { Partial trisomy 9p22-9p24.2 in combination } \\
\text { with partial monosomy 9pter in a Syrian girl }\end{array}$ \\
\hline $\begin{array}{l}\text { Saudi Journal of Kidney Diseases } \\
\text { and Transplantation }\end{array}$ & Ibn-Alnafis Medical Complex & 2008 & $\begin{array}{l}\text { Cyclosporin-A induced posterior reversible } \\
\text { encephalopathy syndrome }\end{array}$ \\
\hline $\begin{array}{l}\text { Saudi Journal of Kidney Diseases } \\
\text { and Transplantation }\end{array}$ & Ibn-Alnafis Medical Complex & 2004 & $\begin{array}{l}\text { Varicella-induced remission of } \\
\text { steroid-resistant nephrotic syndrome in a } \\
\text { child }\end{array}$ \\
\hline Dermatology Online Journal & Ministry of Health & 2005 & $\begin{array}{l}\text { Keratosis lichenoides chronica: Report of } \\
\text { a new case with partial response to PUVA } \\
\text { therapy }\end{array}$ \\
\hline Dermatology Online Journal & Ministry of Health, Syria-Hama & 2009 & $\begin{array}{l}\text { Treatment of crusted scabies with } \\
\text { albendazole: } A \text { case report }\end{array}$ \\
\hline $\begin{array}{l}\text { Saudi Journal of Kidney Diseases } \\
\text { and Transplantation }\end{array}$ & $\begin{array}{l}\text { Division of Pediatric Nephrology, Surgical } \\
\text { Kidney Hospital, Ibn-Alnafis Medical } \\
\text { Complex, Damascus, Syria }\end{array}$ & 2008 & $\begin{array}{l}\text { Cyclosporin-A induced posterior reversible } \\
\text { encephalopathy syndrome }\end{array}$ \\
\hline Dermatology Online Journal & Ministry of Health, Syria-Hama & 2003 & Cicatricial alopecia due to sarcoidosis \\
\hline $\begin{array}{l}\text { Journal of Experimental and } \\
\text { Clinical Cancer Research }\end{array}$ & $\begin{array}{l}\text { Molecular Biology and Biotechnology } \\
\text { Department, Human Genetics Division, } \\
\text { Atomic Energy Commission of Syria, } \\
\text { Damascus-Syria }\end{array}$ & 2007 & $\begin{array}{l}\text { A complex translocation } \mathrm{t}(5 ; 9 ; 22) \text { in } \\
\text { Philadelphia cells involving the short arm } \\
\text { of chromosome } 5 \text { in a case of chronic } \\
\text { myelogenous leukemia }\end{array}$ \\
\hline Dermatology Online Journal & Ministry of Health, Syria-Hama & 2005 & $\begin{array}{l}\text { Multiple cutaneous hemangiomas } \\
\text { accompanied by hepatic hemangiomas }\end{array}$ \\
\hline Human Immunology & $\begin{array}{l}\text { Damascus University, College of } \\
\text { Medicine, Syrian Arab Republic }\end{array}$ & 2014 & $\begin{array}{l}\text { Successful kidney transplant in a patient } \\
\text { with IgG anti-HLA Class-I auto-antibodies: } \\
\text { A case report }\end{array}$ \\
\hline Medical Principles Practice & $\begin{array}{l}\text { Departments of Biochemistry and } \\
\text { Medicine, Damascus University, } \\
\text { Damascus, Syria }\end{array}$ & 2008 & $\begin{array}{l}\text { A } 290 \text {-base-pair deletion in the beta-globin } \\
\text { gene causing } \beta \text {-thalassemia in Syria }\end{array}$ \\
\hline Avicenna Journal of Medicine & $\begin{array}{l}\text { Pediatric Endocrinology and Metabolic } \\
\text { Diseases Unit, University Children } \\
\text { Hospital, Faculty of Medicine, Damascus } \\
\text { University, Damascus, Syria }\end{array}$ & 2014 & Kenny-Caffey syndrome type I \\
\hline Avicenna Journal of Medicine & Damascus University, Faculty of Medicine & 2013 & $\begin{array}{l}\text { Renal artery embolization for managing } \\
\text { uncontrolled hypertension in a kidney } \\
\text { transplant candidate }\end{array}$ \\
\hline $\begin{array}{l}\text { Journal of International Oral } \\
\text { Health }\end{array}$ & Albaath & 2014 & $\begin{array}{l}\text { An unusual side effect of ibuprofen post } \\
\text { dental therapy: Increased erectile and libido } \\
\text { activity }\end{array}$ \\
\hline Digital Journal of Ophthalmology & $\begin{array}{l}\text { Department of Ophthalmology, } \\
\text { Mouassat University Hospital, Damascus } \\
\text { University }\end{array}$ & 2013 & $\begin{array}{l}\text { Artisan iris-fixated toric phakic intraocular } \\
\text { lens for the correction of high astigmatism } \\
\text { after deep anterior lamellar keratoplasty }\end{array}$ \\
\hline $\begin{array}{l}\text { Journal of Fertilization: } \\
\text { In-vitro - IVF-Worldwide, } \\
\text { Reproductive Medicine, Genetics } \\
\text { and Stem Cell Biology }\end{array}$ & Damascus University & 2014 & $\begin{array}{l}\text { A rare inherited reciprocal translocation } \\
\text { found in two male infertile siblings }\end{array}$ \\
\hline
\end{tabular}




\section{CONCLUSION}

The multifactorial reasons for lacking case reports productivity in Syria, especially among medical students, fall in the big picture of major deficiency in research and reflect the weak supportive system. Focusing on medical students is strategic and a pivotal step to face the existing reality. Practical research workshops supported by a national board with defined goals, professional supervision by faculty members who have experience in writing skills, introducing attractive and creative opportunities in the school curriculum, are all important requirements for proper environment for future scientists.

\section{Financial support and sponsorship}

Nil.

\section{Conflicts of interest}

There are no conflicts of interest.

\section{REFERENCES}

1. Karamitsos DT. The story of insulin discovery. Diabetes Res Clin Pract 2011;93 Suppl 1:S2-8.

2. Cohen H. How to write a patient case report. Am J Health Syst Pharm 2006;63:1888-92.

3. Burgoyne LN, O'Flynn S, Boylan GB. Undergraduate medical research: the student perspective. Med Educ Online 2010;15:5212.

4. Diab MM, Taftaf RM, Arabi M. Research productivity in Syria: Quantitative and qualitative analysis of current status. Avicenna J Med 2011;1:4-7.

5. Diez C, Arkenau C, Meyer-Wentrup F. The German medical dissertation - time to change? Acad Med 2000;75:861-3.

6. Solomon SS, Tom SC, Pichert J, Wasserman D, Powers AC. Impact of medical student research in the development of physician-scientists. J Investig Med 2003;51:149-56.

7. Alghamdi KM, Moussa NA, Alessa DS, Alothimeen N, Al-Saud AS. Perceptions, attitudes and practices toward research among senior medical students. Saudi Pharm J 2014;22:113-7.

8. Alahdab F, Firwana B, Hasan R, Sonbol MB, Fares M, Alnahhas I, et al. Undergraduate medical students' perceptions, attitudes, and competencies in evidence-based medicine (EBM), and their understanding of EBM reality in Syria. BMC Res Notes 2012;5:431. 